\title{
Antinomi dalam Peraturan Perundang-undangan di Indonesia
}

\author{
Antinomy in Legislation in Indonesia
}

\author{
Zainal Arifin Mochtar \\ Fakultas Hukum Universitas Gadjah Mada \\ Jln. Sosio Justisia, Bulaksumur, Yogyakarta, 55281, Indonesia \\ Tel./Fax:+62-274-512781E-mail: zainalarifinmochtar@yahoo.com \\ Submitted: Nov 11, 2015; Reviewed: Nov 29, 2015; Accepted: Dec 4, 2015
}

\begin{abstract}
A number of reality for laws as a production of Parliament and President was canceled by the Constitutional Court, occur as a result of the legislation matter that plural reflects the injustice and legal uncertainty. The high number of judicial review becomes signal less accommodation of citizen interests and rights in a legislation product. The absence of arrangement harmony made by Parliament gives impact on plural legislation sued. This paper attempts to describe some debate antinomy that characterizes the existence of legislation in Indonesia. The analysis showed, antinomy-conflict-norm in the legislation is one thing that is difficult to avoid, especially given the poor-legislative process in the parliament today. In each establishment of legislation, synchronization and norms harmonization is not a major pressing point, but defeated by transactional politics inter-faction in the parliament that actually looked more dominant. But when these norms conflict constituted a rule of law which are simultaneous, dynamic, and meet legal ideals, would not be a problem. As long as not to cause harm to the fulfillment of constitutional rights of citizens.
\end{abstract}

Keywords: Antinomy; Constitutional Court; Judicial Review

Abstrak: Realita banyaknya undang-undang produksi DPR dan Presiden yang dibatalkan oleh Mahkamah Konstitusi, terjadi sebagai akibat materi muatan undang-undang tersebut yang jamak mencermikan ketidakadilan dan ketidakpastian hukum. Tingginya angka judicial review menjadi sinyal kurang terakomodasinya kepentingan dan hak-hak warga negara dalam sebuah produk perundang-undangan. Tidak adanya keharmonisan pengaturan yang dilakukan DPR itulah yang memberi dampak pada jamaknya undang-undang yang digugat. Tulisan ini mencoba mendeskripsikan beberapa perdebatan antinomi yang mewarnai eksistensi perundang-undangan di Indonesia. Hasil analisis menunjukkan, antinomipertentangan-norma dalam peraturan perundang-undangan adalah satu hal yang sulit terhindarkan, apalagi mengingat buruknya proses legislasi di DPR saat ini. Dalam setiap pembentukan peraturan perundang-undangan, sinkronisasi dan harmonisasinorma bukanlah satu titik tekan yang utama, melainkan terkalahkan oleh politik transaksional antarfraksi di DPR yang justru tampak lebih dominan. Namun bilamana pertentangan norma tersebut justru membentuk satu aturan hukum yang simultan, dinamis, dan memenuhi cita hukum, tentu tidak menjadi persoalan. Selama tidak menimbulkan kerugian bagi pemenuhan hakhak konstitusional (constitutional rights) warga negara.

Kata Kunci: Antinomi; Mahkamah Konstitusi; Judicial Review 


\section{PENDAHULUAN}

"Hal lain yang senantiasa menjadi perhatian kita saat ini, yaitu banyaknya judicial review Undang-Undang (UU) terhadap UndangUndang Dasar (UUD) ke Mahkamah Konstitusi (MK). Pengujian UU ke MK adalah hak setiap orang yang dijamin oleh undangundang. Oleh karena itu, kita memahami makin banyak saja perkara pengujian yang ditangani MK. Hingga saat ini tidak kurang dari 154 perkara, ada yang sudah diputus, ada yang sedang dalam proses dan ada juga yang ditolak karena tidak memenuhi syarat. Pimpinan DPR berharap pengujian UU terhadap UUD di MK, yang terus bertambah jumlahnya, tidak mengurangi kecermatan para Hakim Konstitusi, sehingga putusan yang dikeluarkan harus sesuai dengan kaidah hukum pada umumnya, dan jangan sampai mengeluarkan putusan yang ultra petita, mengingat Putusan MK yang bersifat final. Dewan menegaskan, bahwa apapun putusan yang dikeluarkan oleh MK wajib dihormati dan ditaati oleh semua pihak, termasuk DPR". ${ }^{1}$

Pernyataan di atas adalah penggalan dari pidato Ketua DPR periode 2004-2009, Agung Laksono, pada saat pembukaan masa sidang II 2008-2009. Laksono mengungkapkan kekhawatirannya atas banyaknya undang-undang hasil produksi DPR dan Pre-siden, yang pada akhirnya dibatalkan oleh MK, baik karena materi maupun proses pembentukannya yang inkonstitusional. Dari konten pernyataan Laksono di atas, setidaknya dapat ditangkap dua hal: $\mathrm{Per}$ tama, DPR gelisah dengan eksistensi MK,

Pidato Ketua DPR RI, Pada Rapat Paripurna DPR RI Pembukaan Masa Persidangan II Tahun Sidang 2008-2009, Senin, 24 Nopember 2008. yang memiliki kewenangan untuk melakukan pembatalan undang-undang yang dianggap bertentangan dengan konstitusi, dan putusannya bersifat final dan mengikat (binding). Keberadaan MK menjadi satu satu ancaman tersendiri bagi DPR dalam pelaksaan fungsi pembentukan undangundang; Kedua, Laksono-sebagai Ketua DPR, menginginkan agar DPR berhati-hati dalam proses dan perumusan materi muatan perundang-undangan, guna menghindari kemungkinan dibatalkan oleh MK. Selain itu, Laksono juga sekaligus mengingatkan MK, agar berhati-hati dalam memutuskan setiap perkara pengujian undang-undang.

Banyaknya undang-undang produksi DPR dan Presiden yang dibatalkan oleh MK, terjadi sebagai akibat materi muatan undangundang tersebut yang jamak mencerminkan ketidakadilan dan ketidakpastian hukum. Seringkali pengaturan yang dilakukan DPR justru kontradiktif dengan pengaturan yang telah ada sebelumnya, dan mengingkari ama nat undang-undang dasar, serta tidak sesuai dengan keinginan masyarakat secara luas. Tidak adanya keharmonisan pengaturan yang dilakukan DPR itulah yang memberi dampak pada jamaknya undang-undang, yang diajukan judicial review ke MK. Dalam lima tahun berdirinya MK, seperti dikemukakan Agung Laksono, setidaknya sudah ada sekitar 154 produk legislasi yang diajukan judicial review ke MK. Belum lagi beberapa undang-undang yang berkali-kali diajukan pengujian.

Menurut data Sekretariat Jenderal dan Kepaniteraan MK, hingga akhir 2009, MK sedikitnya telah menerima 247 perkara pengujian undang-undang terhadap UUD 
1945. Pada tahun 2009, MK sedikitnya menerima 78 permohonan pengujian undangundang terhadap UUD 1945, atau melonjak lebih dari dua kali lipat dibanding dengan tahun sebelumnya, 2008, yang hanya 36 perkara diterima. Jumlah ini merupakan terbesar dibanding tahun-tahun sebelumnya, bahkan hingga saat ini kecenderungan tersebut selalu bertahan atau semakin meninggi. Tahun 2010 menerima sekitar 81 perkara. Meningkat lagi di tahun 2011 menjadi 86 perkara. Makin drastis di tahun 2012 menjadi 118 perkara, meski sempat menurun di tahun 2013 menjadi 109 perkara, akan tetapi kembali meroket di tahun 2014 menjadi 140 perkara. $^{2}$

Di luar asumsi membaiknya kesadaran warga negara atas hak-hak konstitusional mereka, yang dibuktikan dengan antusiasme mereka untuk menguji konstitusionalitas undang-undang yang mengatur mereka, tingginya angka pengajuan pengujian undang-undang ke MK, baik atas materi muatan undang-undang, maupun proses penyusunannya, adalah pertanda buruknya kinerja legislasi DPR. Fakta di atas menunjukkan ketidakcermatan DPR dalam menjalankan fungsi substansialnya, membentuk peraturan perundang-undangan yang seharusnya berpihak pada pemajuan dan pemenuhan hakhak konstitusional warga negara, sekaligus memperlihatkan tingginya pertentangan norma-antinomi dalam peraturan perundang-undangan yang diproduksi DPR dan Presiden.

Tingginya angka judicial review menjadi sinyal kurang terakomodasinya kepenti-

2 Lihat laman Mahkamah Konstitusi Republik Indonesia www.mahkamahkonstitusi.go.id ngan-kepentingan dan hak-hak warga negara dalam sebuah produk perundang-undangan. Perihal pengujian undang-undang sebenarnya tidak perlu banyak terjadi, bilamana DPR jeli dalam menentukan materi muatan suatu undang-undang. Perumusan suatu materi undang-undang seharusnya terlebih dahulu dilakukan sinkronisasi dengan pengaturan yang terdapat dalam konstitusi, sebagai norma dasar tertinggi, dilakukan persandingan dengan pengaturan serupa yang telah ada sebelumnya, serta disesuaikan dengan kepentingan atau suara dari konstituen (masyarakat secara luas). Ketelitian dan kecermatan DPR, dengan memformulasi antara aturan yuridis dan situasi sosial di masyarakat, adalah kunci untuk menekan sekecil mungkin adanya pertentangan norma dalam suatu peraturan perundang-undangan.

Jauh-jauh hari, pada mula adanya MK, sesungguhnya DPR telah sering diingatkan untuk lebih serius dalam melakukan pembahasan berbagai rancangan undang-undang, sebab dengan mudahnya MK dapat membatalkan kekuatan mengikat RUU tersebut setelah diundangkan, apabila tidak dilakukan pembahasan secara serius. Tingginya tingkat pengajuan judicial review berimplikasi pula pada melambatnya kinerja legislasi DPR, sebab DPR diharuskan untuk melakukan revisi dengan segara atas undang-undang yang dibatalkan kekuatan mengikatnya oleh MK, agar supaya tidak terjadi kekosongan hukum (recht vacuum), yang dapat berakibat pada terganggunya akses para pencari keadilan (justitiabelen).

Situasi dan fakta-fakta di atas, sesungguhnya menggambarkan adanya suatu antinomi-pertentangan norma yang terus ber- 
kesinambungan dalam setiap norma hukum yang diciptakan. Setiap norma hukumyang mewujud dalam bentuk peraturan perudang-undangan, materi muatan di dalamnya selalu tak dapat melepaskan diri dari suatu antinomi-pertentangan. Istilah 'antinomi' pertama kali digunakan pada 1529, berasal dari bahasa latin 'antinomia', yang berarti 'anti-nomos', atau pertentangan norma. Secara harfiah antinomi berarti, "a contradiction between two apparently equally valid principles or between inferences correctly drawn from such principles - sebuah pertentangan atau kontradiksi antara dua hal yang terlihat sama-equally, dalam sebuah prinsip yang sah-suatu peraturan yang berlaku atau bila disimplifikasikan berarti pertentangan di dalam suatu hukum itu sendiri.

Tulisan ini sendiri tentu tidak sedang mencoba menyelesaikan problem antinomi dalam sistem perundang-undangan di Indonesia. Tulisan ini akan banyak mendeskripsikan beberapa perdebatan antinomi yang mewarnai eksistensi perundang-undangan di Indonesia. Sekadar untuk menggambarkan bahwa perspektif bersifat antinomia sangat eksis dalam peraturan perundang-undangan. Hal ini tentu saja merupakan bagian yang tak terpisahkan dalam perumusan aturan maupun penegakan aturan itu sendiri.

\section{ANALISIS DAN PEMBAHASAN \\ Dari Kant, Konseptualisasi tentang Anti- nomi}

Meskipun jauh-jauh hari, ketika tradisi hukum Yunani kuno berkembang, telah dikenal peristilahan 'antinomia', untuk menunjukan adanya pertentangan dalam diri suatu hukum, konsep antinomi sebagai sebuah dis- kursus dalam pemikiran filsafat, khususnya dalam khazanah pemikiran filsafat hukum, pada mulanya dikembangkan oleh Immanuel Kant, bersamaan dengan berkembangnya pemikiran filsafat di Jerman. Berangkat dari pemikiran David Hume, Kant melalui bukunya "Critique of Pure Reason" yang dipublikasikan pada tahun $1781,{ }^{3}$ mengenalkan konsep antinomi dalam pemikiran filsafat. Sebelumnya, Hume melalui konsep 'determinisme' yang digagas dalam bukunya " $A$ Treatise of Human Nature", 1740, mengungkapkan bahwa 'selalu akan ada pertentangan dalam suatu materi atau prinsip'. Lebih jauh dikatakan Hume:

As this dilemma is an evident consequence of the principle, that every idea arises from a similar impression, so our decision betwixt the propositions of the dilemma is no more doubtful. go far from there being any distinct impression, attending every impression and every idea, that I do not think there are any two distinct impressions, which are inseparably conjoined. ${ }^{4}$

Dari pemikiran Hume, selanjutnya

Kant mengembangkan struktur formal ten-

\footnotetext{
3 "Critique of Pure Reason", first published in 1781, is one of the landmarks of Western philosophy, a radical departure from everything that went before and an inescapable influence on all philosophy since its publication. In this massive work, Kant has three aims. First, he constructs a new theory of knowledge that delivers certainty about the fundamental principles of human experience at the cost of knowledge of how things are in themselves. Second, he delivers a devastating critique of traditional "speculative" metaphysics on the basis of his new theory of knowledge. Third, he suggests how the core beliefs of the Western metaphysical tradition that cannot be justified as theoretical knowledge can nevertheless be justified as objects of "moral faith" because they are the necessary conditions of the possibility of moral agency. Kant started this third project in the Critique of Pure Reason, but would go on to complete it in two other works, Critique of Practical Reason and Critique of the Power of Judgment.

4 David Hume. (2009). A Treatise of Human Nature. Auckland: The Floating Press, hlm. 115.
} 
tang antinomi di dalam pemikiran filsafat atau lima gagasan, antinomi pertama terdiri dari dua bagian. Pemikiran Kant tentang antinomi dapat dilihat dalam kerangka struktur formal antinomi, yang dirumuskan Kant berikut ini: ${ }^{5}$

Tabel 1. Struktur Formal Antinomi

\begin{tabular}{|c|c|c|}
\hline Antinomy & $\Phi$ (Given) & R (R-condition) \\
\hline First (time) & State of the world & Precedes \\
\hline First (space) & Spatial world region & Properly encloses \\
\hline Second & Composite body & Is a (proper) part of \\
\hline Third & Alteration & $\begin{array}{l}\text { Grounds the causal } \\
\text { power producing }\end{array}$ \\
\hline Fourth & Alteration & $\begin{array}{l}\text { Grounds the (contin- } \\
\text { gent) existence of }\end{array}$ \\
\hline
\end{tabular}

Menurut Kant, keempat struktur formal antinomi di atas akan mengungkap beberapa pertanyaan mendasar berikut ini: ${ }^{6}$

1. Does the world have a beginning in time? A limit in space?

2. Is matter composed of simple substances or divisible to infinity?

3. Does the causality producing any event in nature depend on a spontaneous cause beyond nature?

4. Is nature (or any part of it) necessarily existent?

Menjawab empat pertanyaan dasar di atas, dijelaskan Kant, bahwa antinomi pertama berfokus pada pembatasan dunia yang terbatas oleh ruang dan waktu (the limitation of the universe in respect of space and time). Kant menegaskan, bahwa keterbatasan ruang dan waktu itulah yang memberikan intuisi murni, sebagai sesuatu yang sangat penting dan tanpa batas, tetapi dibatasi oleh perta-

5 Immanuel Kant. (2010). Critique of Pure Reason. Cambridge: Cambridge University Press, hlm. 251. Ibid., hlm. 252-256. nyaan untuk apa sesungguhnya dunia? Sedangkan, antinomi kedua mendasarkan pada kategori kualitas atau komposisi susbtansi materi (it concerns the composition of substance in appearance, or matter). Sementara antinomi ketiga berangkat dari posisi, atau pandangan yang dipahami bersama, bahwa ada hubungan sebab akibat antara satu materi dengan materi lainnya, yang kesemuanya membentuk keteraturan (the problem of free will in relation to universal causality). Terakhir, antinomi keempat, menjelaskan gagasan tentang saling membutuhkan, yang akan menciptakan suatu argumentasi pemikiran tentang kesadaran adanya kebutuhan (the existence of a necessary being). ${ }^{7}$

Sederhananya, Kant ingin menganalisis dunia sebagaimana tampak pada kesa-daran manusia, bahwa emosi menjadi pengertian melalui bentuk ruang dan waktu. Pengertian tersebut kemudian menjadi pengalaman melalui kategori-kategori pengertian, seperti substansi, kualitas, dan kausalitas. Penilaian atas pengalaman tersebut selanjutnya dihubungkan satu sama lain melalui prinsip-prinsip umum. Pendekatan Kant ini didasarkan pada pertentangan fundamental antara akal dan alam. Menurutnya, alam mengikuti kebutuhan, sedangkan akal manusia adalah bebas karena manusia dapat menentukan tujuannya sendiri dan mempunyai kehendak bebas. ${ }^{8}$

Berangkat dari pemikiran Kant tentang antinomi itulah, kemudian berkembang pula

Ibid.

8 W. Friedmann. (1990). Teori dan Filsafat Hukum, Telaah Kritis atas Teori-teori Hukum (Susunan II). Penerjemah Arifin, M. Jakarta: Rajawali Pers, hlm. 2. Bandingkan dengan Timothy M. Costelloe. (2003). "Hume, Kant, and the Antinomy of Taste", Journal of the History of Philosophy, 41(2): 165183. 
pemikiran tentang antinomi di dalam teori hukum, atau pun antinomi-pertentangan norma di dalam suatu aturan hukum. Melanjutkan konseptualisasi yang dilakukan Kant, hukum ditempatkan pada suatu kerangka mendasar untuk menjawab permasalahan apa tujuan hidup yang sesungguhnya? Manusia kemudian berupaya untuk menjawab persoalan mendasar tersebut, melalui sebuah proses dialektika, yang digambarkan Hegel penuh dengan perpecahan, fragmentasi, pertentangan dan aporia, dengan harapan akan melahirkan suatu pemikiran analitik yang bisa menjadi kesimpulan umum. ${ }^{9}$ Namun demikian, hingga saat ini peradaban barat tak pernah menemukan kata sepakat tentang tujuan hidup yang tertinggi, dalam tataran teoritik sekalipun. ${ }^{10}$

Dalam rangka mencapai tujuan hidup itulah, hukum kemudian diciptakan. Meski penuh dengan fragmentasi dan pertentangan, keseimbangan dalam masyarakat harus dicapai. Salah satunya cara, adalah dengan mengakomodasi dua hal yang sebetulnya saling berseberangan atau bertentangan satu sama lain. Akan tetapi keduanya harus selalu ada secara simultan, yang terejawantahkan dalam suatu kaedah hukum. Seperti halnya hak yang selalu diikuti dengan kewajiban, dan keduanya menjadi satu kesatuan dalam suatu kaedah hukum. Meneruskan teorisasi Kant, dua hal yang bertentangan, seperti dimaksud di atas, tetapi keduanya memiliki watak kausalitas dan harus selalu ada secara simultan, itulah yang kemudian

$9 \quad$ Alan Norrie. (2000). "From Critical to Socio-Legal Studies: Three Dialectics in Search of a Subject". Journal Social and Legal Studies, 9:85. Dapat diakses di: http://sls.sagepub.com/content/9/1/85.

10 W. Friedmann, (1990). Op.Cit., hlm. 33. disebut dengan antinomi di dalam kaidah hukum atau peraturan perundang-undangan. ${ }^{11}$

Tentang antinomi di dalam teori hukum atau kaidah hukum itu sendiri, Friedmann menjelaskan, bahwa pertentangan-pertentangan itu terjadi sebagai akibat dari posisi alamiah hukum itu sendiri, yang berdiri di antara nalar filsafat, dan kebutuhan praktis politik-kepentingan. Kategori-kategori intelektual hukum dibangun dari penalaran filsafat yang panjang dan holistik, sedangkan cita-cita keadilan di dalam hukum dikontruksikan melalui sebuah mekanisme politik yang cenderung transaksional. ${ }^{12}$ Akibatnya, hukum bukanlah sesuatu yang terjadi secara alamiah, melainkan merupakan hasil-resultante dari beraneka ragamnya proses internalisasi, intrusi, dan negosiasi berbagai kepentingan di antara faksi-faksi dan aktoraktor dalam masyarakat.

Menurut Gustav Radbruch, cita hukum (Idee des Rechts) — yang dilembagakan dalam suatu bentuk negara hukum, dapat diklasifikasikan ke dalam 3 (tiga) prinsip umum, yaitu: purposiveness - kemanfaatan (Zweckmassigkeit), justice-keadilan (Gerechtigkeit), dan legal certainty - kepastian hukum (Rechtssicherheit). Idealnya ketiga unsur tersebut haruslah terdapat dalam hukum, baik undang-undang maupun putusan hakim, secara proporsional atau berimbang, jangan sampai salah satu unsurnya tidak terakomodasi. Kendati demikian, untuk membuat hukum yang benar-benar proporsional, sesungguhnya sangatlah sulit, karena cita hukum yang satu dengan yang lain, pada dasarnya memiliki nilai-nilai yang saling
${ }_{11}$ Ibid. 
bertentangan-kontradiksi (antinomi), misalnya antara kepastian dan keadilan. ${ }^{13}$ Oleh karenanya, hukum yang berlaku dalam suatu masyarakat hukum, haruslah perimbangan dari beragam antinomi, seperti halnya formulasi antara kepastian hukum dan keadilan. Hubungan tarik-menarik di antara dua antinomi ini menunjukkan dinamika suatu masyarakat hukum. Masyarakat dan dinamikanya adalah sebuah objek bagi kajian sosiologis. Hukum yang berkembang dalam suatu masyarakat yang dinamis itu, di sisi lain, memiliki beragam pengertian. ${ }^{14}$

Sedangkan menurut W. Friedmann, dalam perkembangan teori hukum sedikitnya memiliki enam antinomi di dalamnya, yaitu terdiri dari: ${ }^{15}$

1. Individu dan alam semesta;

2. Kesukarelaan dan pengetahuan objektif;

3. Akal dan intuisi;

4. Stabilitas dan perubahan;

5. Positivisme dan idealisme;

6. Kolektivisme dan individualisme;

7. Demokrasi dan otokrasi;

8. Internasionalisme dan nasionalisme.

Antinomi antara individu dan alam semesta menurut Friedman menggambarkan posisi manusia yang menyandang dua posisi sekaligus, yaitu posisinya sebagai makhluk ciptaan Tuhan dalam hubungannya dengan

13 Torben Spaak, "Meta-Ethic and Legal Theory: The Case of Gustav Radbruch", Journal Law and Philosophy, 28(3): 261-290. Lihat juga, Heather Leawoods. (2000). "Gustav Radbruch: An Extraordinary Legal Philosopher". Journal of Law and Policy, (2): 489-515.

14 Purnadi Purbacaraka dan Soerjono Soekanto. (1986). Sendi-sendi Ilmu Hukum dan Tata Hukum. Bandung: Alumni, hlm. 2-4. Lihat juga, Purnadi Purbacaraka dan Soerjono Soekanto. (1991). Ikhtisar Antinomi Aliran Filsafat sebagai Landasan Filsafat Hukum. Jakarta: Rajawali Pers.

15 W. Friedmann, Op. Cit., hlm. 34-44. alam, dan posisinya yang mengharuskan selalu berhubungan dengan manusia lainnya. Gambaran posisi ini mengacu pada pendapat Aristoteles yang memandang bahwa manusia mempunyai sifat ganda. Manusia merupakan bagian dari alam dan sekaligus sebagai makhluk berakal yang membedakannya dari alam, tetapi manusia masih tetap merupakan bagian dari tatanan benda-benda alam semesta. ${ }^{16}$

Pertentangan nilai antara kesukarelaan dan pengetahuan objektif, sesungguhnya memiliki keterkaitan erat dengan dengan bentuk antinomi pertama, antara individu dan alam semesta. Dalam hal ini, pokok masalah yang menjadi perhatian adalah pertanyaan, apakah kehendak yang mengatur pengetahuan atau justru pengetahuan yang mengatur kehendak manusia. Pertanyaan ini berkaitan, sebetulnya, dengan persoalan yang lebih mendalam yaitu apakah nilai-nilai objektif itu mungkin ada, ataukah kehendak yang menciptakan penilaian-penilaian atasnya. ${ }^{17}$

Antinomi ketiga dalam teori hukum, adalah antara akal dan intuisi-naluri manusia. Dalam banyak hal, akal dan kepercayaan sering bertentangan dengan naluri-intuisi manusia, khususnya ketika berupaya untuk memahami fenomena kehidupan. Lebih jauh, menurut Friedmann, untuk mengatasi pertentangan tersebut, para pemikir filsafat telah memunculkan sebuah konsep filsafat rasionalisme di abad ke-18 dan aliran positivisme pada abad ke-19, yang memang melihat kehidupan dan kenyataan berdasarkan prinsip kausalitas. Meskipun, antara akal dan naluri merupakan dua hal yang selalu

\footnotetext{
16 Ibid.

17 Ibid.
} 
ada dan berpengaruh bagi manusia. ${ }^{18}$

Antinomi berikutnya adalah stabilitas dan perubahan. Dengan mengutip Roscoe Pound, Friedmann mengungkapkan bahwa hukum harus tetap dan hukum tidak dapat tinggal diam. Oleh karena itu, seluruh pemikiran tentang hukum harus berusaha keras menertibkan tuntutan-tuntutan yang bertentangan dengan kebutuhan stabilitas dan kebutuhan akan perubahan. Perubahan sesungguhnya merupakan suatu keniscayaan bagi setiap masyarakat, namun demikian pada saat yang sama dinamika perkembangan masyarakat itu harus dikendalikan sedemikian rupa, agar tidak terjadi kekacauan (chaos) yang justru kontra produktif terhadap kemajuan manusia itu sendiri. ${ }^{19}$

Positivisme dan idealisme juga merupakan suatu antinomi dalam teori hukum. Pengikut positivisme menganggap, bahwa hukum haruslah ditentukan atau dirumuskan berdasarkan pokok persoalan atau permasalahan yang dihadapi. Keberadaan suatu peraturan hukum disebabkan oleh adanya kebutuhan untuk menyelesaikan atau mengatur suatu persoalan tertentu, sehingga proses pembentukan hukum seperti hubungan sebab-akibat (causality), dengan kondisi yang harus dihadapi. Pada sisi lain, penganut idealisme melahirkan hukum yang berasal dari prinsi-prinsip dasar, yang diambil dari nilai-nilai manusia sebagai makhluk yang memiliki rasio dan etika, tidak hanya berdasarkan persoalan yang dihadapi seharisehari semata. Teori idealisme hukum bertujuan untuk menciptakan aturan-aturan apa yang seyogianya harus dilakukan dan apa yang seyogianya tidak boleh dilakukan oleh manusia, agar tercipta kehidupan yang memberikan jaminan terhadap kepentingankepentingan manusia itu sendiri. ${ }^{20}$

Antinomi selanjutnya, menurut Friedmann, adalah kolektivisme dan individualisme. Menurut Friedmann, pertentangan antara kedua hal di atas, disebabkan oleh karena setiap cita-cita keadilan diambil dari teori politik yang dalam sejarah peradaban barat memang memperlihatkan perdebatan yang kuat antara kelompok kolektivisme dan individualisme. Lebih jauh dikemukakan, kaitannya antara individu dengan masyarakat, setidaknya terdapat 3 sikap dari teori-teori hukum yang ada, yaitu apakah ia menempatkan individu di bawah masyarakat; menempatkan masyarakat di bawah individu; atau berusaha menggabungkan kedua paham yang berlawanan tersebut. ${ }^{21}$

Senada dengan antinomi antara individualisme dan kolektivisme, demokrasi dan otokrasi, menurut Friedmann, juga merupakan suatu bentuk antinomi dalam teori hukum. Demokrasi dan individualisme di satu sisi dipertentangkan dengan otokrasi dan kolektivisme di sisi lain. Bagi Friedmann, teori-teori dari tokoh-tokoh demokrasi, baik Locke maupun Rousseau, tetap tidak sepenuhnya diterima, karena dianggap gagal menjelaskan tentang bagaimana hak mayoritas dapat bergandengan dengan hakhak dasar individu. Dalam konteks yang sama, sebaliknya perkembangan hukum di Amerika telah memberikan contoh yang baik tentang bagaimana melindungi hak-hak individual melalui pengadilan walaupun
18 Ibid. $\begin{array}{ll}20 & \text { Ibid. } \\ 21 & \text { Ibid. }\end{array}$ 
hak-hak tersebut bertentangan dengan kepentingan mayoritas yang terdapat dalam undang-undang. ${ }^{22}$

Antinomi terakhir, dalam teori hukum menurut Friedmann, adalah pertentangan antara internasionalisme dan nasionalisme. Menurut Friedmann, teori-teori hukum individualis sering bersifat kosmopolitan, yang memiliki pandangan lebih luas dan melintasi batas-batas administrasi negara bangsa (state of nation). Sedangkan ajaran hukum kolektivis lebih bersifat nasionalis yang menjadi rohnya negara bangsa. Dalam sejarah pemerintahan terlihat bahwa tuntutan hak asasi, persamaan dan kesederajatan martabat manusia (human dignity), sering dikaitkan dengan perlawanan terhadap negara yang otoriter. Hal inilah yang mendorong lahirnya paham individualis, seperti yang diusung oleh kaum Stoa atau Kant.

Dalam perkembangannya, para tokoh yang memperjuangkan paham individualis ini tidak melihat batas-batas negara sebagai kungkungan dalam memperjuangkan persamaan dan perikemanusiaan, karenanya mereka secara tidak langsung menjadi pendorong internasionalisme. Pada sisi lain, kaum kolektivis seperti Hegel, menjadi pendukung kaum nasionalis, karena mereka menganggap bahwa negara nasional merupakan wadah paling baik bagi masyarakat dan individu. ${ }^{23}$

Dalam teori hukum, sebenarnya tidak hanya terdapat delapan antinomi yang dikemukakan Friedmann. Setiap pertentangan di dalam teori hukum, atau materi peraturan hukum, dapat diklasifikasikan sebagai suatu antinomi-pertentangan. Artinya, secara teoretik antinomi dalam hukum tidak terbatas pada delapan pertentangan di atas. Antinomi adalah sebuah 'konsep pertentangan' yang menjadi pijakan dalam melakukan proses analitik terhadap norma-norma dan nilai-nilai yang terdapat di dalam suatu aturan hukum. Pilar-pilar antinomi itulah yang membentuk pondasi hukum menjadi proporsional dan berimbang, mengurangi ketegangan-ketegangan dalam masyarakat. Karena tidak adanya dominasi antara satu pilar terhadap pilar lainnya.

Menurut Sudikno Mertokusumo, dengan merujuk pada pandangan Scholten, menyebutkan bahwa dalam kondisi tertentu, antinomi dalam hukum juga berkaitan dengan asas hukum yang bersifat umum. Dikatakannya, bahwa selain adanya asas hukum yang terikat dengan waktu dan tempat, juga terdapat asas hukum yang tidak terpengaruh oleh waktu dan tempat. Dalam hal ini, setidaknya terdapat lima asas hukum umum sebagaimana dimaksud yaitu, asas kepribadian, asas persekutuan, asas kesamaan, asas kewibawaan, dan asas pemisahan baik dan buruk. Lebih lanjut dijelaskan Mertokusumo, bahwa empat asas pertama, meski saling bertentangan satu sama lain, yaitu antara kepribadian dengan persatuan, dan kesamaan dengan kewibawaan, namun senantiasa terdapat dalam setiap sistem hukum. Tidak ada sistem hukum yang tidak mengenal keempat asas hukum tersebut.

Dalam praktiknya, memang masingmasing sistem hukum mempunyai kecenderungan yang lebih besar terhadap salah satu asas dan agak kurang perhatian terhadap asas lainnya, tetapi sekecil apa pun keempat asas tersebut selalu menyertai setiap sistem 
hukum. ${ }^{24}$

Dalam perkembangan pemikiran hukum kontemporer, seiring dengan menguatnya neo-liberalisme, Friedrich von Hayek melalui bukunya The Road to Serfdom, mencoba memberikan penjelasan berbeda tentang cita hukum, yang diinginkan kaum neoliberal. Menurut Hayek, dalam pengertian tradisional, terdapat tiga unsur utama dalam sebuah cita hukum, yang terkerangkakan dalam konsep the rule of law. Dikemukakannya, bahwa hukum setidaknya harus memiliki tiga atribut, yaitu berlaku umum (generality), kesetaraan (equality) dan kepastian (certainty). Gagasan Hayek sesungguhnya ditujukan sebagai kontra-wacana terhadap seluruh model-model pemerintahan dan pengaturan terpusat, ditegaskan Hayek, "the rule of law, the absence of legal privileges of particular people designated by authority, is what safeguards that equality before the law which is the opposite of arbitrary government". 25

Berlaku umum (generality) berarti hukum wajib mengikat bagi semua orang, tanpa terkecuali, dan karenanya bentuknya haruslah abstrak. Menurut Hayek, penerapan hukum sebaiknya lebih diutamakan melalui proses adjudikasi. Oleh karenanya, dalam sistem bernegara harus ada pemisahan tegas, antara kekuasaan legislatif dan yudikatif, sehingga hukum yang abstrak dapat diterapkan kepada individu melalui putusan hakim. Sementara kesetaraan (equality) menuntut hukum dapat diberlakukan kepada semua

24 Sudikno Mertokusumo. (1996). Penemuan Hukum, Suatu Pengantar. Yogyakarta: Liberty, hlm. 35.

25 Friedrich Von Hayek. (2005). The Road to Serfdom. London: The Institute of Economic Affairs, hlm. 57-59. orang tanpa terkecuali. Sedangkan kepastian hukum (certainty), berarti hukum dapat diprediksi, atau memenuhi unsur prediktibilitas, sehingga seorang subjek hukum dapat memperkirakan peraturan apa yang mendasari perilaku mereka, dan bagaimana aturan tersebut ditafsirkan dan dilaksanakan. Namun demikian, dalam setiap peraturan hukum, tidak dipungkiri kemungkinan adanya antinomi antara ketiga atribut tersebut. ${ }^{26}$

\section{Menelusuri Antinomi dalam Pemben- tukan Peraturan Perundang-undangan}

Banyaknya peraturan perundang-undangan yang dibatalkan oleh MK, karena dianggap bertentangan dengan Undang-Undang Dasar, memperlihatkan betapa besarnya antinomi dalam peraturan perundang-undangan yang dibentuk oleh DPR bersama Presiden. Uraian di bawah ingin menguraikan beberapa temuan tentang antinomi di dalam pembentukan peraturan perundang-undangan.

Persamaan dan Keadilan, Kemanfaatan dan Kepastian Hukum: Antinomi dalam UU No. 25 Tahun 2007 tentang Penanaman Modal

Pada 10 Januari 1967, dalam masa awal pemerintahan Soeharto, Indonesia mengundangkan UU No. 1 Tahun 1967 tentang Pena naman Modal Asing (PMA), dan kemudian undang-undang tentang Penanaman Modal dalam Negeri (PMDN), diundangkan pada 3 Juli 1968, melalui UU No. 6 Tahun 1968. Menurut pemerintah waktu itu, penanaman modal asing merupakan persoalan yang paling mendesak, karenanya pengaturan

\footnotetext{
26 Ibid.
} 
mekanisme ini harus didahulukan. Setelah berpuluh tahun lamanya, pemerintah melihat, tidak perlu lagi melakukan pembedaan antara penanaman modal asing dengan penanaman modal dalam negeri. Keduanya mesti diberikan hak, fasilitas, dan kewajiban yang sama. Biarkan mekanisme pasar bekerja sepenuhnya, unsur proteksionisme harus dihilangkan.

Semangat yang didorong dalam pembahasan undang-undang ini ialah semangat untuk memberi kemudahan bagi investor, yang di dalamnya antara lain menyangkut: ${ }^{27}$

a. Pemberian kejelasan tentang insentif yang bisa diperoleh para investor;

b. Insentif harus lebih banyak diberikan kepada pusat-pusat pertumbuhan ekonomi yang berada di luar Jawa;

c. Memberikan kepastian tentang bidangbidang yang tidak bisa dimasuki;

d. Insentif bagi para investor yang mau menarik dananya, yang sebelumnya dilarikan ke luar negeri;

e. Persyaratan modal minimal bagi investor asing, agar tidak merambah sektor usaha mikro kecil dan menengah;

f. Perlunya koordinasi penanaman modal antar lembaga-lembaga terkait;

g. Adanya percepatan dalam pengurusan prosedur perijinan; dan

h. Mekanisme dan aturan teknis yang diciptakan oleh pemerintah harus mampu mendorong investasi dari para investor domestik.

Pembahasan RUU Penanaman Modal yang diusulkan oleh pemerintah itu, dapat dibaca sebagai upaya legalisasi liberalisasi

27 Sekretariat Jenderal DPR RI, Risalah Pembahasan RUU Penanaman Modal, 2007. perekonomian nasional. Hal ini terlihat dari beberapa klausula substantif yang akan didorong dalam materi undang-undang, seperti disebutkan di atas. Munculnya rancangan undang-undang ini, merupakan bagian dari paket perbaikan kebijakan iklim investasi yang dikeluarkan melalui Instruksi Presiden Nomor 3 Tahun 2006 yang salah satu programnya adalah mengubah UU Penanaman Modal. Menurut INPRES ini, UU Penanaman Modal di dalamnya harus memuat prinsip-prinsip dasar: perluasan definisi modal, transparansi, perlakuan sama investor domestik dan asing (di luar negative list), dan dispute settlement. Selain UU Penanaman Modal, undang-undang lain yang termasuk dalam paket perbaikan kebijakan investasi ialah undang-undang tentang resi gudang. ${ }^{28}$

Meskipun tujuan dari pembentukan undang-undang penanaman modal adalah menjamin adanya persamaan antara penanam modal dalam negeri dengan penanam modal asing, namun pada materi muatan pengaturannya, undang-undang ini justru bertentangan dengan rasa keadilan. Hal itu dapat dilihat dari ketentuan Pasal 22 ayat (1) UU No. 25 Tahun 2007, disebutkan:

Kemudahan pelayanan dan/atau perizinan hak atas tanah sebagaimana dimaksud dalam Pasal 21 huruf a dapat diberikan dan diperpanjang di muka sekaligus dan dapat diperbarui kembali atas permohonan penanam modal, berupa:

a. Hak Guna Usaha dapat diberikan dengan jumlah 95 (sembilan puluh lima) tahun dengan cara dapat diberikan dan diperpanjang di muka sekaligus selama 60 (enam puluh) tahun dan dapat diperbarui selama 35 (tiga puluh lima) tahun;

\footnotetext{
28 Ibid.
} 
b. Hak Guna Bangunan dapat diberikan dengan jumlah 80 (delapan puluh) tahun dengan cara dapat diberikan dan diperpanjang di muka sekaligus selama 50 (lima puluh) tahun dan dapat diperbarui selama 30 (tiga puluh) tahun; dan

c. Hak Pakai dapat diberikan dengan jumlah 70 (tujuh puluh) tahun dengan cara dapat diberikan dan diperpanjang di muka sekaligus selama 45 (empat puluh lima) tahun dan dapat diperbarui selama 25 (dua puluh lima) tahun.

Ketentuan Pasal 22 ayat (1) di atas memperlihatkan adanya pertentanganantinomi antara "persamaan" dan "keadilan". Pemerintah berkeinginan agar asas persamaan diterapkan dalam UU Penanaman Modal, dengan tidak adanya pembedaan kebijakan yang diterapkan bagi investor asing dan investor dalam negeri, namun di sisi lain pengaturan tersebut telah mengusik rasa keadilan bagi warganegara umumnya. Ketentuan di dalam UU Penanaman Modal, dianggap banyak bertentangan dengan konstitusi, UUD 1945, khususnya Pasal 28D ayat (1) UUD 1945, yang menyebutkan, "Setiap orang berhak atas pengakuan, jaminan, perlindungan, dan kepastian hukum yang adil serta perlakuan yang sama di hadapan hukum". Selain antinomi antara persamaan dan keadilan, ketentuan Pasal 22 ayat (1) UU Penanaman Modal menunjukan adanya pertentangan antara prinsip "kemanfaatan" dan "kepastian hukum".

Di satu sisi, undang-undang tersebut hendak memberikan kemanfaatan dalam bentuk kemudahan-kemudahan dalam mekanisme penanaman modal di Indonesia, namun di sisi lain, ketentuan tersebut justru ber- tentangan dengan prinsip kepastian hukum. Ketentuan Pasal 22 ayat (1) UU Penanaman Modal menyatakan perpanjangan hak guna usaha (HGU) dapat diperpanjang di muka sekaligus, sementara UU Pokok Agraria No. 5 Tahun 1960 memberikan pengaturan yang berbeda, sehingga muncullah pertentangan, yang berakibat pada tidak adanya kepastian hukum. Pada akhirnya, ketentuan mengenai "diperpanjang di muka sekaligus" yang terdapat pada Pasal 22 ayat (1) dinyatakan tidak memiliki kekuatan hukum mengikat oleh MK. ${ }^{29}$

\section{Generality-Berlaku Umum dan Kepas-} tian Hukum-Dapat Diprediksi: Antinomi dalam UU No. 18 Tahun 2004 tentang Perkebunan

Pada awal pembentukannya, Pemerintah beranggapan bahwa lahirnya UU No. 18 Tahun 2004 tentang Perkebunan merupakan landasan hukum untuk mengembangkan perkebunan, dan upaya mewujudkan kesejahteraan bersama. Sehingga penyelenggaraan perkebunan yang demikian telah sejalan dengan amanat Pasal 33 ayat (3) UUD 1945, yang menyatakan bahwa bumi, air, dan kekayaan alam yang terkandung di dalamnya dikuasai oleh negara dan dipergunakan untuk sebesar-besarnya bagi kemakmuran rakyat.

Permasalahannya kemudian, secara substansial ternyata UU Perkebunan membuka ruang yang luas bagi pelestarian eksploitasi secara besar-besaran perusahaan perkebunan terhadap tanah-tanah rakyat. Hal ini disebabkan karena tidak adanya

29 Putusan MK No. 21-22/PUU-V/2007 tentang Pengujian UU No. 25 Tahun 2007 tentang Penanaman Modal. 
pengaturan mengenai luas maksimum dan luas minimum tanah yang dapat dijadikan sebagai lahan perkebunan, yang pada akhirnya menimbulkan adanya konsentrasi hak penggunaan tanah yang berlebihan oleh perusahaan. Lebih jauh, sebagian besar hak guna usaha yang dimiliki perusahaan perkebunan, lambat laun menggusur keberadaan masyarakat adat atau petani yang berada di sekitar atau di dalam lahan perkebunan. Akibatnya masyarakat adat atau petani tersebut tidak lagi memiliki akses terhadap hak milik yang telah turun temurun mereka kuasai, atau bahkan kehilangan lahannya.

Selain itu, UU Perkebunan juga memberikan ancaman sanksi pidana, bagi setiap orang yang melanggar kewajiban dan melakukan perbuatan yang dilarang dalam undang-undang tersebut. Permasalahan muncul karena muatan materi mengenai 'larangan melakukan suatu perbuatan' sebagaimana yang diatur dalam Pasal 21 dan Pasal 47 ayat (1) dan (2) UU Perkebunan, dirumuskan secara samar-samar, tidak jelas dan rinci. Sehingga berpotensi dan memberikan peluang dan keleluasaan untuk disalahgunakan. Akibatnya, ketentuan pasal tersebut seringkali digunakan untuk memidanakan masyarakat umum yang berkonflik dengan perusahaan perkebunan. Ketentuan Pasal 21 UU No. 18 Tahun 2004 tentang Perkebunan menyebutkan, "Setiap orang dilarang melakukan tindakan yang berakibat pada kerusakan kebun dan/atau aset lainnya, penggunaan tanah perkebunan tanpa izin dan/atau tindakan lainnya yang mengakibatkan terganggunya usaha perkebunan”. Sementara Pasal 47 ayat (1) dan (2) menyebutkan: a. Setiap orang yang dengan sengaja melanggar larangan melakukan tindakan yang berakibat pada kerusakan kebun dan/atau aset lainnya, penggunaan lahan perkebunan tanpa izin dan/atau tindakan lainnya yang mengakibatkan terganggunya usaha perkebunan sebagaimana dimaksud dalam Pasal 21, diancam dengan pidana penjara paling lama 5 (lima) tahun dan denda paling banyak $R p$ 5.000.000.000,00 (lima milyar rupiah);

b. Setiap orang yang karena kelalaiannya melakukan tindakan yang berakibat pada kerusakan kebun dan/ atau asset lainnya, penggunaan lahan perkebunan tanpa izin dan/atau tindakan lainnya yang mengakibatkan terganggunya usaha perkebunan sebagaimana dimaksud dalam Pasal 21, diancam dengan pidana penjara paling lama 2 (dua) tahun 6 (enam) bulan dan denda paling banyak $R p$ 2.500.000.000,00 (dua miliar lima ratus juta rupiah).

Kedua ketentuan di atas, memperlihatkan adanya pertentangan antara prinsip berlaku umum (generality), sehingga bentuknya harus abstrak, dengan prinsip kepastian hukum-dapat diprediksi (certainty). Dilihat dari muatannya, Pasal 21 dan Pasal 47 ayat (1) dan (2) UU Perkebunan, terang tidak mencerminkan aturan yang jelas, mudah dipahami, dan dapat dilaksanakan secara adil. Rumusan delik pemidanaan dalam pa sal-pasal tersebut adalah rumusan yang tidak jelas dan berpotensi disalahgunakan secara sewenang-wenang.

Ketentuan tersebut kontradiksi dengan konsep hukum, yang menyatakan bahwa, " $a$ legal system in which rules are clear, wellunderstood, and fairly enforced", dengan unsur kepastian hukum di dalamnya, dan sekaligus 
mengandung asas legalitas, prediktibilitas, dan transparansi. ${ }^{30}$

Ketentuan Pasal 21 dan Pasal 47 ayat (1) dan (2) di atas, juga mencerminkan adanya pembedaan kedudukan dan perlakuan (unequal treatment), ketidakadilan (injustice), ketidakpastian hukum (legal uncertainty), serta bersifat diskriminatif terhadap warga negara pada umumnya. Sebab, dengan adanya ketentuan kedua pasal dimaksud, setiap tindakan yang dilakukan dalam rangka mempertahankan dan memperjuangkan hakhaknya, serta membela hak-hak masyarakat dapat dikualifikasi secara sewenang-wenang menjadi suatu perbuatan yang dapat ditafsirkan dan dikualifikasi sebagai "merintangi dan menggangu jalannya usaha perkebunan". Padahal menuntut suatu hak baik individu maupun kolektif dijamin oleh berbagai perundang-undangan termasuk UUD 1945, sehingga mengakibatkan dilanggarnya jaminan kepastian hukum, sebagaimana diatur dalam Pasal 28D ayat (1) UUD 1945. ${ }^{31}$

\section{Ketertiban dan Keadilan, Demokrasi dan} Otokrasi: Antinomi dalam UU No. 4/PNPS/ 1963 tentang Pelarangan Barang Cetakan MK telah pernah memutuskan permohonan pengujian UU No. 4/PNPS/1963 tentang Pelarangan Barang-Barang Cetakan jo. Pasal 30 hurufC UU No. 16 Tahun 2004 tentang Kejaksaan. Menurut MK, ketentuan Pasal 1 hingga Pasal 9 UU No. 4/PNPS/1963 adalah inkonstitusional, bertentangan dengan UUD 1945. Kedua peraturan di atas pada intinya memberikan kewenangan absolut pada kejaksaan untuk melakukan pengawasan, pela-

\footnotetext{
30 PIL-Net, Permohonan Pengujian UU No. 18 Tahun 2004 tentang Perkebunan, terhadap UUD 1945.

31 Ibid.
}

rangan, pengamanan, dan penyitaan terhadap barang-barang cetakan yang isinya dianggap dapat mengganggu ketertiban umum.

Namun sayangnya, pelarangan peredaran barang-barang cetakan yang dilakukan oleh kejaksaan tidak pernah disertai dengan alasan dan bukti-bukti yang kuat mengenai "sejauh mana mengganggu dan membahayakannya buku-buku tersebut jika diketahui oleh masyarakat banyak". Sehingga patut diduga bahwa alasan pelarangan tersebut hanya didasarkan pada kecurigaan bahwa bukubuku tersebut mengandung muatan isu-isu yang berkaitan komunisme, marxisme dan SARA, atau bahkan sekadar suka atau tidak suka (like or dislike) dari pihak penguasa, terhadap pihak tertentu. Kejaksaan Agung juga tidak menelaah dan mendiskusikan lebih lanjut dengan pihak-pihak terkait (penulis, penerbit, akademisi, dan masyarakat sipil) mengenai muatan materi dan dampak yang akan timbul dari diterbitkannya buku-buku tersebut.

Selain itu, sebagai negara pihak dari Konvensi Internasional Hak Sipil dan Politik, yang telah diratifikasi melalui UU No. 12 Tahun 2005, Indonesia terikat pada standar hak asasi manusia yang berlaku secara universal dalam melakukan pembatasan atas penikmatan hak, khususnya terkait dengan hak kebebasan berekspresi dan menyatakan pendapat sebagaimana dimuat dalam General Comment No. 10 Kovenan Internasional Hak Sipil dan Politik yang telah diadopsi PBB sejak tahun 1983 dan lebih lanjut diatur melalui Prinsip-prinsip Siracusa yang diadopsi pada tahun 1984. Berdasarkan prinsip ini, penghormatan atas hak asasi manusia justru seharusnya menjadi salah satu elemen 
dasar yang tercakup dalam pengertian "kepentingan umum". Dengan demikian, tindakan pembredelan justru menunjukkan kontradiksi atas pemahaman kepentingan umum yang semestinya.

Lebih jauh, tindakan pelarangan yang dilakukan oleh Kejaksaan Agung tanpa melalui sebuah mekanisme pengadilan, merupakan bentuk pelanggaran serius terhadap instrumen-instrumen hak asasi manusia yang secara yuridis telah dibentuk dan berlaku di wilayah Indonesia, antara lain UUD 1945, UU No. 39 Tahun 1999 tentang Hak Asasi Manusia, dan UU No 12 Tahun 2005 tentang Ratifikasi Kovenan Hak-hak Sipil dan Politik, serta TAP MPR No. XVII tentang Hak Asasi Manusia. Pasal 28F UUD 1945 jo. Pasal 14 UU No. 39 Tahun 1999, secara jelas menyatakan:

"Setiap orang berhak untuk berkomunikasi dan memperoleh informasi untuk mengembangkan pribadi dan lingkungan sosialnya, serta berhak untuk mencari, memperoleh, memiliki, menyimpan, mengolah, dan menyampaikan informasi dengan menggunakan segala jenis saluran yang tersedia".

Demikian juga dengan Kovenan Hakhak Sipil dan Politik yang menyatakan bahwa:

"Setiap orang akan berhak mempunyai dan menyatakan pendapat tanpa diganggu, termasuk kebebasan mencari, menerima dan memberikan informasi dan segala macam gagasan tanpa memperhatikan batas, baik secara lisan maupun tulisan atau tercetak, dalam bentuk seni, atau melalui sarana lain menurut pilihannya sendiri".

Terhadap hak-hak ini tidak diperkenankan adanya pengecualian atau pembatasan apapun oleh negara.
Dalam teori antinomi, pengaturan hukum di dalam ketentuan UU No. 4/ PNPS/1963 memperlihatkan adanya kontradiksi antara prinsip "ketertiban" dan "keadilan", dan juga prinsip "demokrasi” dan “otokrasi”. Pada satu sisi, negera khususnya pemerintah berkuasa, berkeinginan untuk terus-menerus menjaga keteraturan, demi menjaga stabilitas dan kontinuitas pemerintahannya. Namun aturan yang diterapkan penguasa justru bertentangan dengan prinsip-prinsip keadilan yang menjadi hak dari setiap warganegara. Selain itu, negara juga menyatakan bahwa prinsip demokrasi diutamakan dan diterapkan dalam seluruh kegiatan penyelenggaraan negara, akan tetapi memerhatikan aturan-aturan yang masih berlaku justru merefleksikan dilanggengkannya prinsip otokrasi dalam penyelenggaraan pemerintahan.

Terkait dengan aturan tersebut, dalam pertimbangan hukum putusannya, MK menyatakan, bahwa ketentuan Pasal 1 hingga Pasal 9 UU No. 4/PNPS/1963 bertentangan dengan Pasal 1 ayat (3) dan Pasal 28 ayat (1). Menurut MK suatu negara hukum, mutlak adanya "due process of law", yaitu penegakan hukum dalam suatu sistem peradilan. Apabila ada suatu perbuatan dikategorikan sebagai perbuatan melawan hukum, maka prosesnya harus melalui putusan pengadilan, sehingga pelarangan peredaran suatu barang cetakan yang dianggap dapat mengganggu ketertiban umum, tidak dapat diserahkan kepada suatu instansi tanpa melalui putusan pengadilan. Kewenangan Jaksa Agung melarang peredaran barang cetakan tanpa melalui proses peradilan merupakan salah satu pendekatan negara kekuasaan, bukan negara 
hukum. ${ }^{32}$

Selain itu, penyitaan barang cetakan tanpa melalui proses peradilan, menurut MK adalah sama dengan pengambilalihan hak milik pribadi secara sewenang-wenang yang amat dilarang oleh Pasal $28 \mathrm{H}$ ayat (4) UUD 1945 yang menegaskan, "Setiap orang berhak mempunyai hak milik pribadi dan hak milik tersebut tidak boleh diambil alih secara sewenang-wenang oleh siapa pun". Tindakan pengambilalihan barang cetakan tanpa prosedur yang benar menurut hukum, terutama tanpa melalui proses peradilan, merupakan suatu eksekusi tanpa peradilan (extra judicial execution) yang sangat ditentang dalam suatu negara hukum yang menghendaki due process of law. Ditegaskan MK, due process of law, adalah penegakan hukum melalui suatu sistem peradilan.

Untuk ketentuan Pasal 30 huruf C, MK menyatakan bahwa frasa "pengawasan peredaran barang cetakan", khususnya kata "Pengawasan" tidak dapat dimaknai sebagai "Pengamanan". Lebih jauh menurut MK, "pengawasan" dapat ditafsirkan sebagai mekanisme penyelidikan, penyidikan, penyitaan, penggeledahan, penuntutan, dan penyidangan oleh instansi yang berwenang, sesuai dengan due process of law, yang berujung pada putusan pengadilan, dan selanjutnya kejaksaan sebagai eksekutornya. ${ }^{33}$

Nasionalisme dan Universalisme Hak Asasai Manusia: Antinomi dalam Pengesahan Konvenan Internasional tentang Hak-hak Ekosob dan Hak-hak Sipol Tahun 2005

Wacana pengesahan International Covenant on Economic, Social and Cultural Rights

\footnotetext{
32 Putusan MK Nomor 6-13-20/PUU-VIII/2010. 33 Ibid.
}

(ICESCR) 1967 dan International Covenan on Civil and Political Rights (ICCPR) 1976, menjadi undang-undang nasional, baru mengemuka beberapa tahun setelah reformasi. Ada beberapa alasan yang melatarbelakangi pengesahan kedua kovenan tersebut, menjadi undang-undang nasional, antara lain disebutkan: ${ }^{34}$

a. Undang-Undang Dasar 1945 telah secara tegas menyebutkan, bahwa Indonesia adalah negara hukum yang menjunjung tinggi hak asasi manusia, sebagaimana tertuang dalam pasal-pasal UUD 1945, khususnya yang berkait dengan pemajuan dan perlindungan hak asasi manusia;

b. Refleksi praktik pelanggaran hak asasi manusia yang terjadi di masa lalu, sehingga ada kewajiban negara untuk memperbaikinya;

c. Ketetapan MPR No. XVII/MPR/1998 yang memberi amanat kepada Presiden dan DPR untuk mengesahkan berbagai instrumen Perserikatan Bangsa-Bangsa, tentang hak asasi manusia, sepanjang tidak bertentangan dengan Pancasila dan UUD 1945;

d. Rekomendasi dari Rencana Aksi Nasional Hak Asasi Manusia (RAN HAM) 1998-2003, yang dituangkan dalam Keputusan Presiden No. 129 Tahun 1998, dan ditegaskan kembali dalam RAN HAM 2004-2009, sebagaimana disebutkan dalam Keputusan Presiden No. 40 Tahun 2004. RAN HAM 2004 2009, menempatkan pengesahan kedua kovenan internasional hak asasi

34 Setjen DPR, Risalah pembahasan RUU Pengesahan ICESCR dan ICCPR, 2005. 
manusia tersebut, sebagai prioritas yang utama.

Meski secara umum, substansi Kovenan Internasional tentang Hak-hak Ekonomi, Sosial dan Budaya, dan Kovenan Internasional tentang Hak-hak Sipil dan Politik, memiliki urgensi yang signifikan bagi upaya pemajuan, pemenuhan dan penegakan hak asasi manusia di Indonesia. Namun pernyataan keberatan dalam undang-undang pengesahan kedua kovenan tersebut, telah menjadi catatan tersendiri, tentang sejauh mana komitmen negara terhadap hak asasi manusia.

Dalam Pasal 1 ayat (1) UU No. 11 Tahun 2005, disebutkan: "Mengesahkan International Covenant on Economic, Social and Cultural Rights (Kovenan Internasional tentang Hak-hak Ekonomi, Sosial dan Budaya) dengan Declaration (Pernyataan) terhadap Pasal 1". Sementara dalam Pasal 1 ayat (1) UU No. 12 Tahun 2005, disebutkan, "Mengesahkan International Covenant on Civil and Political Rights (Kovenan Internasional tentang Hak-hak Sipil dan Politik) dengan Declaration (Pernyataan) terhadap Pasal 1".

Pernyataan keberatan-deklarasi da lam pengesahan kedua kovenan hak asasi manusia tersebut, memperlihatkan adanya pertentangan - antinomi antara prinsip "nasionalisme" dan "universalisme hak asasi manusia". Prinsip universal hak asasi manusia menghendaki adanya kesamaan dan jaminan hak bagi setiap manusia, termasuk untuk menentukan nasibnya sendiri. Sedangkan prinsip nasionalisme menumbuhkan kekhawatiran bahwa pengakuan terhadap jaminan tersebut, akan melahirkan perpecahan atau disintegrasi wilayah-wilayah republik.

Sesungguhnya dalam Pasal 1 Kovenan Internasional tentang Hak-hak Ekonomi, Sosial dan Budaya, serta Kovenan Internasional tentang Hak-hak Sipil dan Politik, secara lengkap disebutkan sebagai berkut:

1) Semua bangsa mempunyai hak untuk menentukan nasibnya sendiri yang memberikan mereka kebebasan untuk menentukan status politik kebebasan untuk memperoleh kemajuan ekonomi, sosial dan budaya.

2) Semua bangsa dapat, demi kepentingan mereka sendiri, secara bebas mengelola kekayaan dan sumber daya alam mereka tanpa mengurangi kewajiban-kewajiban yang mungkin timbul dari kerjasama ekonomi internasional berdasarkan prinsip saling menguntungkan dan hukum internasional. Dalam hal apapun tidak dibenarkan suatu bangsa dirampas sumber-sumber hajat hidupnya.

3) Negara Pihak dalam Kovenan ini, termasuk mereka yang bertanggung jawab atas administrasi atas wilayahwilayah Perwalian, harus memajukan hak penentuan nasib sendiri, dan menghormatinya sesuai dengan ketentuan-ketentuan Piagam Perserikatan Bangsa-Bangsa.

Dari pernyataan keberatan tersebut, setidaknya dapat dilihat, bahwa sesungguhnya pengesahan kedua kovenan tersebut, merupakan sekadar upaya untuk meningkatkan citra Indonesia di mata internasional. Kendati penolakan terhadap klausula hak untuk menentukan nasib sendiri (the rights of self determination), dibungkus dengan alasan ketakutan negara - pemerintah dan DPR — akan munculnya ancaman pemisahan (disintegration) dari beberapa wilayah Indonesia, yang selama ini bergejolak. Akan tetapi, pilihan itu 
sebenarnya memperlihatkan, adanya keengganan negara untuk melakukan upaya serius, dalam pemenuhan dan penegakan hak asasi manusia, yang diakui dan dijamin oleh kedua kovenan tersebut.

Deklarasi terhadap ketentuan Pasal 1 Kovenan Internasional tentang Hak-hak Ekonomi, Sosial dan Budaya, dan Kovenan Internasional tentang Hak-hak Sipil dan Politik, menunjukan adanya kontradiksi dalam sikap dan komitmen negara. Pada satu sisi, negara hanya mengakui satu bangsa Indonesia, namun dengan deklarasi ini menjadikan sikap negara mendua. Pernyataan ini memberi pertanda, bahwa negara sesungguhnya mengakui adanya bangsa-bangsa lain, selain Indonesia dalam negara Indonesia. Oleh karena dalam kovenan ini sudah ditegaskan, hanyalah bangsa (nation) yang memiliki hak untuk menentukan nasib sendiri-sebagai negara merdeka, bukan dalam artian rakyat (people). Sebab itu, pernyataan keberatan terhadap ketentuan Pasal 1 kovenan, pada dasarnya justru kontradiktif dengan Mukadimah UUD 1945, di mana Indonesia mengakui bahwa kemerdekaan adalah hak segala bangsa.

Kemanfaatan dan Kepastian Hukum: Antinomi dalam UU No. 30 Tahun 2002 tentang Komisi Pemberantasan Korupsi

Pada tingkat pembentukan peraturan perundang-undangan, negara pada dasarnya telah memberikan komitmen yang cukup serius bagi upaya pemberantasan tindak pidana korupsi. Hal itu ditandai dengan dikeluarkannya beberapa regulasi yang memberi legitimasi bagi langkah dan gerakan pemberantasan korupsi. Salah satunya adalah pembentukan UU No. 30 Tahun 2002 tentang Komisi Pemberantasan Tindak Pidana Korupsi. Pembentukan komisi independen ini dimaksudkan untuk memaksilkan langkah pemberantasan korupsi, termasuk korupsi yang dilakukan oleh aparat penegak hukum, polisi, jaksa, hakim, dan advokat. Sebagaimana diketahui, institusi-institusi penegak hukum, juga menjadi kubangan bagi koruptor untuk memperkaya diri. Mafia hukum dan peradilan merajalela, sehingga tidaklah mungkin jikalau upaya pemberantasan korupsi diserahkan sepenuhnya pada mereka.

Komisi Pemberantasan Korupsi (KPK) menjalankan tugas penyelidikan, penyidikan, dan penuntutan sekaligus, demi efektivitas kerja pemberantasan korupsi. Namun demikian, kehadiran KPK juga tidak menutup ruang bagi kepolisian dan kejaksaan dalam tugas-tugas pemberantasan korupsi. KPK diharapkan menjadi motor terdepan dalam pemberantasan korupsi, mengingat buruknya sistem kerja dan perilaku para penegak hukum di institusi penegak hukum lainnya, yang kurang berpihak pada upaya pemberantasan korupsi. Hal ini terbukti dengan begitu banyaknya para tersangka dan terdakwa kasus korupsi yang lepas begitu saja dari jerat hukum. Padahal tindakanya secara kasat mata telah merongrong keuangan negara.

Undang-undang ini juga sekaligus mengamanatkan pembentukan pengadilan khusus tindak pidana korupsi, untuk menyelesaikan kasus-kasus korupsi yang proses penyelidikan, penyidikan, dan penuntutannya dilakukan oleh KPK. Perihal itu sebagaimana diatur di dalam Pasal 53 UU No. 30 
Tahun 2002, disebutkan:

"Dengan Undang-Undang ini dibentuk Pengadilan Tindak Pidana Korupsi yang bertugas dan berwenang memeriksa dan memutus tindak pidana korupsi yang penuntutannya diajukan oleh Komisi Pemberantasan Korupsi."

Pengadilan khusus ini berada di dalam lingkungan peradilan umum, sebagaimana diatur di dalam UU Kekuasaan Kehakiman, dan hanya ada pada Pengadilan Negeri Jakarta Pusat. Berbeda dengan pengadilan umum lainnya, pada pengadilan tindak pidana korupsi ini, majelis hakimnya terdiri dari hakim karir dan hakim ad-hoc. Keberadaan hakim ad-hoc dimaksudkan untuk menghadirkan orang-orang yang memiliki keahlian khusus, terkait dengan seluk-beluk dan polapola kejahatan tindak pidana korupsi.

Selain itu, kehadiran hakim ad-hoc juga sekaligus menjawab ketidakpercayaan masyarakat terhadap integritas dan kinerja hakim karir, yang perilakunya cenderung korup, dan tunduk pada perintah-perintah informal institusi pengadilan di atasnya. Dengan adanya hakim ad-hoc ini, diharapkan suatu kasus tindak pidana korupsi akan terungkap secara menyeluruh, dan mampu menyeret semua aktor yang bermain, serta akan terjaga integritas dan kewibawaan putusannya.

Pembentukan pengadilan khusus tersebut, telah melahirkan satu pertentangan antara "asas kemanfaatan", adalah hal pentingnya pemberantasan korupsi, dan "asas kepastian hukum", terkait dengan adanya dualisme peradilan pidana tindak pidana korupsi. Antinomi di dalam UU KPK tersebut, pada akhirnya berakhir dengan mekanisme pengujian Pasal 53 UU No. 30 Tahun 2002 tentang Komisi Pemberantasan Tindak Pidana Korupsi (UU KPK), yang mengamanatkan pembentukan pengadilan khusus tindak pidana korupsi terhadap UUD 1945. Pengujian terhadap pasal ini sangatlah berkontroversi, sebab menentukan ada tidaknya pengadilan khusus tindak pidana korupsi untuk masa selanjutnya, yang berarti menentukan hidup matinya massifikasi gerakan pemberantasan korupsi di Indonesia.

Memang, bilamana dilihat dari tempat pengaturannya, amanat pembentukan pengadilan khusus tindak pidana korupsi, yang ditempatkan di dalam UU KPK, secara konstitusional bermasalah, karena ada pencampuradukan antara ranah kekuasan eksekutif dan yudikatif. Di dalam Pasal 24A UUD 1945 hasil amendemen ketiga, pada ayat (5) disebutkan, "Susunan, kedudukan, keanggotaan, dan hukum acara Mahkamah Agung serta badan peradilan di bawahnya diatur dengan undang-undang". Ketentuan undang-undang dasar ini kemudian didetailkan melalui UU No. 4 Tahun 2004 tentang Kekuasaan Kehakiman.

Di dalam penjelasan Pasal 15 ayat (1) UU Kekuasaan Kehakiman diterangkan, "Pengadilan khusus hanya dapat dibentuk dalam salah satu lingkungan peradilan sebagaimana dimaksud dalam Pasal 10 yang diatur dengan undang-undang". Artinya, menjadi bermasalah, ketika pembentukan pengadilan khusus tindak pidana korupsi, tidak diatur secara tersendiri, dengan undangundang yang mengatur pembentukan dan proses beracara pada pengadilan dimaksud.

Selain permasalahan teknis penempatan peraturan perundang-undangan, antinomi antara kemanfaatan dan kepastian hu- 
kum juga menjadi problem mendasar dalam materi muatan UU KPK. Kendati demikian, melihat situasi kontekstual dan kondisi penegakan hukum di negeri ini, yang masih memerlukan tindakan luar biasa, khususnya dalam upaya pemberantasan korupsi, dalam putusan pengujian UU KPK, MK menyatakan, meskipun Pasal 53 UU No. 30 Tahun 2002 tentang Komisi Pemberantasan Tindak Pidana Korupsi (UU KPK) bertentangan dengan UUD 1945, namun tetap mempunyai kekuatan hukum mengikat sampai diadakan perubahan paling lambat tiga tahun terhitung sejak putusan diucapkan. ${ }^{35}$

Lebih jauh menurut MK, ketentuan Pasal 53 ini terang bertentangan dengan UUD 1945, sebab kehadiran pasal tersebut nyata-nyata telah menimbulkan dualisme penanganan perkara tindak pidana korupsi, yang berimplikasi pada terlanggarnya hakhak konstitusional warganegara, khususnya para tersangka kasus koruspi. Kendati demikian MK masih memertimbangkan bahwa: ${ }^{36}$

1. Akibat hukum atas kekuatan mengikat Pasal 53 UU KPK tersebut harus cukup memertimbangkan agar proses peradilan Tipikor atas pemeriksaan perkara yang sedang ditangani tidak terganggu atau tidak macet, apa lagi menimbulkan kekacauan hukum;

2. Putusan yang diambil oleh Mahkamah jangan sampai menyebabkan timbulnya ketidakpastian hukum (rechtsonzekerheid) yang dapat mengakibatkan kekacauan dalam penanganan atau pemberantasan tindak pidana korupsi;

\footnotetext{
35 Putusan MK Nomor: 012-016-019/PUU-IV/2006, tanggal 19 Desember 2006

36 Ibid.
}

3. Putusan Mahkamah tersebut jangan sampai pula menimbulkan implikasi melemahnya semangat (disinsentive) pemberantasan korupsi yang telah menjadi musuh bersama bangsa dan masyarakat Indonesia;

4. Untuk melakukan penyempurnaan UU KPK dan penataan kelembagaan pengadilan khusus yang diperlukan untuk itu, tidak dapat diselesaikan seketika, sehingga dibutuhkan waktu yang cukup.

Dalam putusannya, MK juga menyatakan, agar supaya tidak terjadi kekacauan dalam proses peradilan tindak pidana korupsi, MK memerintahkan kepada pembentuk undang-undang untuk sesegera mungkin melakukan penyelarasan UU KPK dengan UUD 1945 dan membentuk Undang-Undang tentang Pengadilan Tipikor dalam kerangka pengadilan khusus, sebagai satu-satunya sistem peradilan tindak pidana korupsi, sehingga dualisme sistem peradilan tindak pidana korupsi yang telah dinyatakan bertentangan dengan UUD 1945 dapat dihilangkan. Penegasan MK tersebut, sesungguhnya merupakan upaya menghindari terjadinya kembali pertentangan norma-antinomi di dalam peraturan perundang-undangan yang memberi legitimasi dalam pemberantasan tindak pidana korupsi.

\section{PENUTUP}

Antinomi-pertentangan norma-dalam per aturan perundang-undangan adalah satu hal yang sulit terhindarkan, apalagi mengingat buruknya proses legislasi di DPR saat ini. Dimana dalam setiap pembentukan peraturan perundang-undangan, sinkronisasi 
dan harmonisasi norma bukanlah satu titik tekan yang utama, melainkan terkalahkan oleh politik transaksional antarfraksi di DPR yang justru tampak lebih dominan. Namun demikian, bilamana pertentangan norma tersebut, justru membentuk satu aturan hukum yang simultan, dinamis, dan memenuhi cita hukum, tentu tidak menjadi persoalan. Selama tidak menimbulkan kerugian bagi pemenuhan hak-hak konstitusional warganegara. Hal itu dapat dipahami, karena memang dalam teori hukum terdapat halhal yang saling bertentangan (antinomi), yang harus diakomodasi secara proporsional dalam hukum agar tidak bias terhadap salah satu pihak, sehingga muncul keteganganketegangan.

Berhadapan dengan antinomi tentu saja diperlukan kearifan. Pembentuk undangundang dalam konteks positive legislature, maupun $\mathrm{MK}$ sebagai negative legislature tentu tak bisa menghilangkannya, karena itu menjadi bagian integral dari kerangka hukum itu sendiri. Namun bukan berarti tak bisa diselesaikan secara arif dan bijaksana dengan kembali ke pemenuhan hak konstitusional warga. Alasan hukum (legal reasoning) tepat dan kuat itulah yang akan sangat membantu menyelesaikan ketegangan yang lahir dari antinomia ini.

\section{BIBLIOGRAFI}

Alan Norrie. (2000). "From Critical to Socio-Legal Studies: Three Dialectics in Search of a Subject". Journal Social and Legal Studies, 9:85. Available online at: http://sls.sagepub.com/content/9/1/85.
David Hume. (2009). A Treatise of Human Nature. Auckland: The Floating Press. Diane Collinson and Kathryn Plant. (2007). Fifty Major Philosophers. London: Routledge.

Friedrich Von Hayek. (2005). The Road to Serfdom. London: The Institute of Economic Affairs.

Heather Leawoods. (2000). "Gustav Radbruch: An Extraordinary Legal Philosopher". Journal of Law and Policy, (2): 489-515.

Immanuel Kant. (2010). Critique of Pure Reason. Cambridge: Cambridge University Press.

Purnadi Purbacaraka dan Soerjono Soekanto. (1986). Sendi-sendi Ilmu Hukum dan Tata Hukum. Bandung: Alumni.

Purnadi Purbacaraka dan Soerjono Soekanto. (1991). Ikhtisar Antinomi Aliran Filsafat sebagai Landasan Filsafat Hukum. Cetakan pertama. Jakarta: Rajawali Pers.

Sudikno Mertokusumo. (1996). Penemuan Hukum, Suatu Pengantar. Yogyakarta: Liberty.

Timothy M. Costelloe. (2003). "Hume, Kant, and the Antinomy of Taste", Journal of the History of Philosophy, 41(2): 165183.

Torben Spaak, "Meta-Ethic and Legal Theory: The Case of Gustav Radbruch", Journal Law and Philosophy, 28(3): 261-290.

W. Friedmann. (1990). Teori dan Filsafat Hukum, Telaah Kritis atas Teori-teori Hukum (Susunan II). Penerjemah Arifin, M. Jakarta: Rajawali Pers. 